\title{
FAKTOR-FAKTOR YANG BERHUBUNGAN DENGAN PEMBERIAN SUSU FORMULA PADA BAYI USIA 0-6 BULAN DI WILAYAH KERJA PUSKESMAS JEMBATAN KECIL KOTA BENGKULU
}

\section{Factors Associated with Formula Milk Feeding in Baby Age 0-6 Months in Working Area Jembatan Kecil Public Health Center Bengkulu}

\author{
Suryani $^{1}$, Yusran Fauzi ${ }^{1}$, Popyta Sari $^{1}$ \\ ${ }^{1}$ Program Studi Kesehatan Masyarakat STIKES Tri Mandiri Sakti Bengkulu \\ Email:S Suryanilise@yahoo.co.id
}

\begin{abstract}
ABSTRAK
Susu formula adalah susu yang dibuat dari susu sapi atau susu buatan yang diubah komposisinya hingga dapat dipakai sebagai pengganti air susu ibu (ASI). Penelitian ini bertujuan untuk untuk mempelajari faktor-faktor yang berhubungan dengan pemberian susu formula pada bayi usia 0-6 bulan di Wilayah Kerja Puskesmas Jembatan Kecil Kota Bengkulu. Penelitian ini adalah survey analitik dengan menggunakan desain Cross Sectional. Populasi dalam penelitian ini adalah seluruh ibu yang mempunyai bayi usia >6-12 bulan di Wilayah Kerja Puskesmas Jembatan Kecil Kota Bengkulu. Teknik pengambilan sampel pada penelitian ini menggunakan Proposional Random Sampling dan diperoleh sampel sebanyak 68 orang ibu bayi. Pengumpulan data dalam penelitian menggunakan data primer dan sekunder.Teknik analisis data dilakukan dengan analisis univariat dan bivariat dengan uji statistik Chi-Square $\left(\chi^{2}\right)$ melalui program SPSS. Hasil penelitian didapatkan: dari $68 \mathrm{ibu}$, terdapat $40 \mathrm{ibu}(58,8 \%)$ melakukan pemberian susu formula, $31 \mathrm{ibu}(45,6 \%)$ berpengetahuan cukup, $50 \mathrm{ibu}(73,5 \%)$ mengatakan petugas kesehatan menyarankan pemberian susu formula, dan 34 ibu (50,0\%) tidak terpapar. Penelitian ini menunjukkan ada hubungan yang signifikan antara pengetahuan ibu, petugas kesehatan dan iklan susu formula dengan pemberian susu formula pada bayi usia 0-6 bulan di wilayah kerja Puskesmas Jembatan Kecil Kota Bengkulu. Disarankan kepada petugas kesehatan untuk dapat melakukan penyuluhan kepada ibu hamil dan ibu nifas tentang peranan penting ASI eksklusif bagi bayi, ibu, keluarga, masyarakat dan negara sehingga program pemberian ASI eksklusif di Kota Bengkulu dapat berjalan sesuai harapan.
\end{abstract}

Kata Kunci : bayi, iklan, pengetahuan, pemberian susu formula, petugas, kesehatan 


\begin{abstract}
Milk formula is milk made from cow's milk or artificial milk that changed its composition to be used as a substitute for breast milk (breast milk). This study aimed to study factors related to formula milk feeding in infants aged 0-6 months in working area of Jembatan Kecil Public Health Center Bengkulu. This research was an Analytical Survey and used Cross Sectional design. The population in this study were all mothers with babies > 6-12 months old in working area of Jembatan Kecil Public Health Center Bengkulu. Sampling technique in this research used Random Sampling Proposal and obtained samples of 68 baby mothers. Data collection in research used primary and secondary data. Data analysis technique was done by univariate and bivariate analysis with Chi-Square statistical test $\left(\chi^{2}\right)$ through SPSS program. The result of this study was : from 68 respondents there were 40 mothers (58.8\%) did formula milk feeding, 31 mothers (45.6\%) had enough knowledge, 50 mothers (73.5\%) said health workers recommended formula milk feeding, and 34 mothers (50.0\%) were not exposed with formula milk advertising. This study showed that there was a significant relationship between maternal knowledge, health officer, and formula milk advertising with infant formula feeding in working area of Jembatan Kecil Public Health Center Bengkulu. It was advisable to health workers to be able to counsel pregnant and postpartum women about the important role of exclusive breastfeeding for babies, mothers, families, communities and countries so that exclusive breastfeeding program in Bengkulu could run as expected.
\end{abstract}

Keywords : advertising, formula milk feeding, health officer, infants, knowledge

\section{A. Pendahuluan}

Susu formula adalah susu yang dibuat dari susu sapi atau susu buatan yang diubah komposisinya hingga dapat dipakai sebagai pengganti air susu ibu (ASI) (Irianto, 2014). Makanan terbaik bagi bayi sebenarnya bukanlah susu formula, tetapi ASI eksklusif. ASI eksklusif adalah makanan terbaik yang harus diberikan kepada bayi karena didalamnya terkandung hampir semua zat gizi yang dibutuhkan oleh bayi. Tidak ada yang dapat menggantikan ASI karena ASI didesain khusus untuk bayi, sedangkan komposisi susu sapi (susu sapi segar atau susu formula yang sudah diformulasikan khusus untuk bayi) sangat berbeda sehingga tidak dapat menggantikan ASI (Yuliarti, 2010).

ASI adalah makanan utama bayi sehingga tidak ada jenis makanan lainnya yang dapat menandingi kualitas
ASI. Hanya ASI saja yang dapat diterima oleh sistem pencernaan bayi sehingga ASI harus diberikan secara eksklusif selama 6 bulan. Bayi yang mendapatkan ASI eksklusif selama 6 bulan pertama akan mengalami pertumbuhan otak yang optimal pada bagian otak dan kemampuan anak dalam bahasa, motorik, dan juga emosi (Astuti et al, 2015).

Dampak yang terjadi jika bayi tidak mendapatkan ASI eksklusif yaitu bayi yang tidak mendapatkan ASI atau mendapatkan ASI tidak eksklusif memiliki resiko kematian karena diare 3,94 kali lebih besar dibandingkan dengan bayi yang mendapat ASI eksklusif. Berdasarkan hasil penelitian didapatkan bahwa bayi yang diberikan susu formula lebih sering mengalami diare dibandingkan dengan bayi yang mendapat ASI eksklusif. Di Amerika, tingkat kematian bayi pada bulan 
pertama berkurang sebesar $21 \%$ pada bayi yang disusui. (Astuti et al, 2015).

Berdasarkan data World Health Organization (WHO) menyebutkan bahwa hampir $90 \%$ kematian balita terjadi di Negara berkembang dan lebih dari $40 \%$ kematian tersebut disebabkan diare dan infeksi saluran pernapasan akut, yang dapat dicegah dengan pemberian ASI eksklusif sedangkan cakupan ASI eksklusif diseluruh dunia hanya 39\% (Monika, 2014). Angka pemberian ASI eksklusif di Eropa pada usia bayi 6 bulan bervariasi dari sebanyak $46 \%$ di Austria dan $42 \%$ di Swedia hingga $21 \%$ di Inggris (UK) dan $10 \%$ di Jerman (Gibney et al,2009). Hasil penelitian yang dilakukan United Nationd Children's Fund (UNICEF), mengemukakan bahwa bayi yang diberi susu formula dibawah 6 bulan memiliki kemungkinan meninggal dunia pada bulan pertama kelahirannya dan peluang itu 25 kali lebih tinggi dari pada bayi yang disusui ibunya secara eksklusif (Nurmawati et al, 2015).

Di Indonesia, pada tahun 2007 angka kematian bayi adalah 35 per 1000 kelahiran hidup. Karena itu, Organisasi Kesehatan Dunia merekomendasikan semua bayi perlu mendapat kolostrum (ASI hari pertama dan kedua) untuk melawan infeksi, dan ASI eksklusif selama 6 bulan untuk menjamin kecukupan gizi bayi (Mulyani, 2013).

Pencapaian di Indonesia masih dirasakan sangat jauh dari kenyataan bila dibandingkan dengan target yang diharapkan pada tahun 2014 sekurangkurangnya $80 \%$ bayi yang mendapatkan ASI eksklusif, yaitu hanya ASI saja tanpa makanan ataupun minuman lain sejak lahir sampai umur 6 bulan. Berdasarkan prevalensi ASI eksklusif dari Data Survei Demografi dan Kesehatan Indonesia (SDKI) dari tahun 2002-2003 pada bayi sampai usia 4 bulan hanya $55 \%$ dan sampai usia 6 bulan sebesar 39,5\% (Maryunani, 2012).Dan terus menurun pada tahun 2007 yaitu sebanyak 32\% (Susanto et al, 2015), kemudian menurun lagi sebanyak 27\% pada tahun 2012. Sedangkan penggunaan susu formula pada bayi yang mendapat ASI yaitu pada usia 0-1 bulan sebanyak $34,5 \%$, bayi usia $2-3$ bulan $24,4 \%$, bayi usia $4-$ 5 bulan $22,6 \%$ dan bayi usia 6-8 bulan $23,5 \%$ dan penggunaan susu formula padap bayi yang tidak mendapat ASI yaitu pada usia 0-1 bulan sebanyak $75,7 \%$,bayi usia $2-3$ bulan sebanyak $94,4 \%$, bayi usia $4-5$ bulan sebanyak $88,5 \%$, bayi usia 6-8 bulan sebanyak $81,4 \% \quad$ (SDKI, 2012).Prevalensi terbesar pemberian prelakteal pada bayi yaitu susu formula sebesar 79,8\% (Kemenkes RI, 2013).

Berdasarkan data Dinas Kesehatan Provinsi Bengkulu tahun 2015,pemberian ASI eksklusif sebanyak 19.286 (52\%) dari 36910 bayi yang ada, dengan rincian 9.595 (53\%) bayi laki-laki dan 9691 (52\%) bayi perempuan. Cakupan bayi yang mendapatkan ASI eksklusif di 10 (sepuluh) Kabupaten/Kota antara lain Bengkulu Selatan sebanyak 57\%, Rejang Lebong sebanyak 47\%, Bengkulu Utara sebanyak 58\%, Kaur sebanyak $74 \%$, Seluma sebanyak $45 \%$, Muko-Muko sebanyak 54\%, Lebong sebanyak 73\%, Kepahiang sebanyak $61 \%$, Bengkulu Tengah sebanyak $41 \%$ dan Kota Bengkulu sebanyak 38\%. Sehingga didapatkan cakupan ASI eksklusif tertinggi adalah Kabupaten Kaur sebesar $74 \%$ dan cakupan terendah ada di Kota Bengkulu yaitu sebesar 38\%. Bila dibandingkan dengan target Nasional tahun 2014 sebesar $80 \%$ maka cakupan pemberian ASI eksklusif di Provinsi Bengkulu masih rendah, terlihat bahwa Kota Bengkulu 
adalah Kota dengan urutan terendah bayi yang diberi ASI eksklusif (Dinkes Provinsi Bengkulu, 2015).

Data Dinas Kesehatan Kota Bengkulu, dari 20 (dua puluh) Puskesmas induk di Kota Bengkulu cakupan data ASI eksklusif tertinggi adalah di Puskesmas Padang Serai sebanyak $278(93,3 \%)$ dan data ASI eksklusif paling rendah adalah di Puskesmas Bentiring 28 (54,9\%) dan Puskesmas Jembatan Kecil 107 (56,3\%) (Dinkes Kota Bengkulu, 2015).

Rumusan masalah dalam penelitian ini adalah "Faktor-faktor apa saja yang berhubungan dengan pemberian susu formula pada bayi usia 0-6 bulan di wilayah kerja Puskesmas Jembatan Kecil Kota Bengkulu? Tujuan penelitian ini adalah untuk mempelajari faktor-faktor yang berhubungan dengan pemberian susu formula pada bayi usia 0-6 bulan di wilayah kerja Puskesmas Jembatan Kecil Kota Bengkulu.

\section{B. Metode Penelitian}

Penelitian ini dilaksanakan di wilayah kerja Puskesmas Jembatan
Kecil Kota Bengkulu pada bulan Juni 2017. Jenis penelitian ini adalah survey analitik dengan pendekatan Cross Sectional. Populasi dalam penelitian ini adalah seluruh ibu yang mempunyai bayi usia > 6-12 bulan tinggal di wilayah kerja Puskesmas Jembatan Kecil Kota Bengkulu sebanyak 215 orang. Pengambilan sampel dalam penelitian ini dilakukan dengan teknik Proportional Random Sampling. Teknik pengumpulan data menggunakan data primer dan data sekunder. Teknik analisis data menggunakan analisis univariat dan analisis bivariat. Data dianalisis dengan menggunakan uji statistic Chi-Square $\left(\chi^{2}\right)$. Untuk mengetahui keeratan hubungannya digunakan uji statistik Contingency Coefficent (C).

\section{Hasil Penelitian}

\section{Analisis Univariat}

Analisis univariat bertujuan untuk menggambarkan distribusi frekuensi faktor pengetahuan ibu, faktor petugas kesehatan, faktor iklan susu formula dan pemberian susu formula di wilayah kerja Puskesmas Jembatan Kecil Kota Bengkulu.

Tabel 1

Distribusi Frekuensi Pengetahuan Ibu di Wilayah Kerja Puskesmas Jembatan Kecil Kota Bengkulu

\begin{tabular}{clcc}
\hline No & Pengetahuan & Frekuensi & Persentase $(\%)$ \\
\hline 1 & Kurang & 12 & 17,6 \\
2 & Cukup & 31 & 45,6 \\
3 & Baik & 25 & 36,8 \\
& Jumlah & 68 & 100,0 \\
\hline
\end{tabular}

Berdasarkan Tabel 1 dapat ibu $(45,6 \%)$ berpengetahuan cukup dan dilihat bahwa dari $68 \mathrm{ibu}$, terdapat $12 \quad 25 \mathrm{ibu}(36,8 \%)$ berpengetahuan baik. ibu $(17,6 \%)$ berpengetahuan kurang, 31 
Tabel 2

Distribusi Frekuensi Petugas Kesehatan di Wilayah Kerja Puskesmas Jembatan Kecil Kota Bengkulu

\begin{tabular}{cccc}
\hline No & Petugas Kesehatan & Frekuensi & Persentase (\%) \\
\hline 1 & Tidak Menyarankan & 18 & 26,5 \\
2 & Menyarankan & 50 & 73,5 \\
& Jumlah & 68 & 100,0 \\
\hline
\end{tabular}

Berdasarkan Tabel 2 dapat dan 50 petugas $(73,5 \%)$ yang dilihat bahwa dari 68 petugas, terdapat menyarankan. 18 petugas $(26,5 \%)$ tidak menyarankan,

Tabel 3

Distribusi Frekuensi Iklan Susu Formula di Wilayah Kerja Puskesmas Jembatan Kecil Kota Bengkulu

\begin{tabular}{clcc}
\hline No & Iklan Susu Formula & Frekuensi & Persentase (\%) \\
\hline 1 & Terpapar & 34 & 50,0 \\
2 & Tidak Terpapar & 34 & 50,0 \\
& Jumlah & 68 & 100,0 \\
\hline
\end{tabular}

Berdasarkan Tabel 3 dapat formula, dan $34 \mathrm{ibu}(50,0 \%)$ yang dilihat bahwa dari $68 \mathrm{ibu}$, terdapat 34 tidak terpapar iklan susu formula. ibu $(50,0 \%)$ terpapar iklan susu

Tabel 4

Distribusi Frekuensi Pemberian Susu Formula di Wilayah Kerja Puskesmas Jembatan Kecil Kota Bengkulu

\begin{tabular}{clcc}
\hline No & Pemberian Susu Formula & Frekuensi & Persentase (\%) \\
\hline 1 & Diberikan & 40 & 58,8 \\
2 & Tidak Diberikan & 28 & 41,2 \\
& Jumlah & 68 & 100,0 \\
\hline
\end{tabular}

Berdasarkan Tabel 4 dapat dilihat bahwa dari $68 \mathrm{ibu}$, terdapat 40 ibu $(58,8 \%)$ memberikan susu formula, dan $28 \mathrm{ibu}(41,2 \%)$ yang tidak memberikan susu formula.

\section{Analisis Bivariat}

Analisis bivariat bertujuan untuk mengetahui hubungan antara variabel bebas (faktor pengetahuan ibu, faktor petugas kesehatan dan faktor iklan susu formula) dengan variabel terikat (pemberian susu formula) di wilayah kerja Puskesmas Jembatan Kecil Kota Bengkulu. 
Tabel 5

Hubungan Pengetahuan Ibu dengan Pemberian Susu Formula Pada Bayi Usia 0-6 Bulan di Wilayah Kerja Puskesmas Jembatan Kecil Kota Bengkulu

\begin{tabular}{|c|c|c|c|c|c|c|c|c|c|}
\hline \multirow{3}{*}{ Pengetahuan } & \multicolumn{4}{|c|}{ Pemberian Susu Formula } & \multirow{2}{*}{\multicolumn{2}{|c|}{ Total }} & \multirow{3}{*}{$\chi^{2}$} & \multirow{3}{*}{$\mathrm{P}$} & \multirow{3}{*}{$\mathrm{C}$} \\
\hline & \multicolumn{2}{|c|}{ Diberikan } & \multicolumn{2}{|c|}{$\begin{array}{c}\text { Tidak } \\
\text { Diberikan }\end{array}$} & & & & & \\
\hline & $\mathrm{F}$ & $\%$ & $\mathrm{~F}$ & $\%$ & $\mathrm{~F}$ & $\%$ & & & \\
\hline Kurang & 10 & 83,3 & 2 & 16,7 & 12 & 100,0 & & & \\
\hline Cukup & 22 & 71,0 & 9 & 29,0 & 31 & 100,0 & م2 20 & רחם 0 & 0301 \\
\hline Baik & 8 & 32,0 & 17 & 68,0 & 25 & 100,0 & 12,290 & 0,002 & 391 \\
\hline Total & 40 & 58,8 & 28 & 41,2 & 68 & 100,0 & & & \\
\hline
\end{tabular}

Berdasarkan Tabel 5 dapat diketahui bahwa dari 12 orang ibu dengan pengetahuan kurang terdapat 10 orang ibu yang memberikan susu formula dan 2 orang ibu tidak memberikan susu formula, dari 31 orang ibu dengan pengetahuan cukup terdapat 22 orang ibu yang memberikan susu formula dan 9 orang ibu yang tidak memberikan susu formula sedangkan 25 orang ibu dengan pengetahuan baik terdapat 8 orang ibu yang memberikan susu formula dan 17 orang ibu yang tidak memberikan susu formula.
Hasil uji Pearson Chi-Square didapat sebesar 12,290 dengan nilai asymp.sig $(p)=0,002$. Karena nilai $\mathrm{p}<0,05$ maka ada hubungan yang signifikan antara faktor pengetahuan ibu dengan pemberian susu formula pada bayi usia 0-6 bulan di Wilayah Kerja Puskesmas Jembatan Kecil Kota Bengkulu. Hasil uji Contigency Coefficient (C) didapat sebesar 0,391. Karena nilai tersebut tidak terlalu jauh dari nilai $\mathrm{C}_{\max }=0,707$ maka hubungan tersebut dikatakan kategori sedang.

Tabel 6

Hubungan Petugas Kesehatan dengan Pemberian Susu Formula pada Bayi Usia 0-6 Bulan di Wilayah Kerja Puskesmas Jembatan Kecil Kota Bengkulu

\begin{tabular}{|c|c|c|c|c|c|c|c|c|c|}
\hline \multirow{3}{*}{$\begin{array}{l}\text { Petugas } \\
\text { kesehatan }\end{array}$} & \multicolumn{4}{|c|}{$\begin{array}{l}\text { Pemberian Susu } \\
\text { Formula }\end{array}$} & \multirow{2}{*}{\multicolumn{2}{|c|}{ Total }} & \multirow{3}{*}{$\chi^{2}$} & \multirow{3}{*}{$\mathrm{p}$} & \multirow{3}{*}{$\mathrm{C}$} \\
\hline & \multicolumn{2}{|c|}{ Diberikan } & \multicolumn{2}{|c|}{$\begin{array}{c}\text { Tidak } \\
\text { Diberikan }\end{array}$} & & & & & \\
\hline & $\mathrm{F}$ & $\%$ & $\mathrm{~F}$ & $\%$ & $\mathrm{~F}$ & $\%$ & & & \\
\hline $\begin{array}{c}\text { Tidak } \\
\text { menyarankan }\end{array}$ & 6 & 33,3 & 12 & 66,7 & 18 & 100,0 & 211 & רבת 0 & 0207 \\
\hline Menyarankan & 34 & 68,0 & 16 & 32,0 & 50 & 100,0 & 5,214 & $0,0<2$ & 0,291 \\
\hline Total & 40 & 58,8 & 28 & 41,2 & 68 & 100,0 & & & \\
\hline
\end{tabular}

Berdasarkan Tabel 6 dapat diketahui bahwa dari 18 orang ibu bayi yang mengatakan petugas kesehatan tidak menyarankan pemberian susu formula pada bayi usia 0-6 bulan, ada
12 orang ibu bayi yang tidak memberikan susu formula pada bayi usia 0-6 bulan dan 6 orang ibu bayi yang memberikan susu formula pada bayi usia $0-6$ bulan sedangkan dari 50 
orang ibu bayi yang mengatakan petugas kesehatan menyarankan pemberian susu formula pada bayi usia 0-6 bulan, ada 16 orang ibu bayi yang tidak memberikan susu formula pada bayi usia 0-6 bulan dan 34 orang ibu bayi yang memberikan susu formula.

Hasil uji Continuity Correction didapat sebesar 5,214 dengan nilai asymp.sig $(\mathrm{p})=0,022$. Karena nilai $\mathrm{p}<0,05$ maka ada hubungan yang signifikan antara faktor petugas kesehatan dengan pemberian susu formula pada bayi usia 0-6 bulan di wilayah kerja Puskesmas Jembatan Kecil Kota Bengkulu. Hasil uji Contigency Coefficient (C) didapat sebesar 0,297. Karena nilai tersebut tidak terlalu jauh dari nilai $\mathrm{C}_{\max =0,707}$ maka hubungan tersebut dikatakan kategori sedang.

Tabel 7

Hubungan Iklan Susu Formula dengan Pemberian Susu Formula pada Bayi Usia 0-6 Bulan di Wilayah Kerja Puskesmas Jembatan Kecil Kota Bengkulu

\begin{tabular}{|c|c|c|c|c|c|c|c|c|c|}
\hline \multirow{3}{*}{$\begin{array}{l}\text { Iklan susu } \\
\text { formula }\end{array}$} & \multicolumn{4}{|c|}{$\begin{array}{l}\text { Pemberian Susu } \\
\text { Formula }\end{array}$} & \multirow{2}{*}{\multicolumn{2}{|c|}{ Total }} & \multirow{3}{*}{$\chi^{2}$} & \multirow{3}{*}{$\mathrm{p}$} & \multirow{3}{*}{$\mathrm{C}$} \\
\hline & \multicolumn{2}{|c|}{ Diberikan } & \multicolumn{2}{|c|}{$\begin{array}{c}\text { Tidak } \\
\text { Diberikan }\end{array}$} & & & & & \\
\hline & $\mathrm{F}$ & $\%$ & $\mathrm{~F}$ & $\%$ & $\mathrm{~F}$ & $\%$ & & & \\
\hline $\begin{array}{l}\text { Tidak } \\
\text { terpapar }\end{array}$ & 13 & 38,2 & 21 & 61,8 & 34 & 100,0 & & & \\
\hline Terpapar & 27 & 79,4 & 7 & 20,6 & 34 & 100,0 & 10,261 & 0,001 & 0,386 \\
\hline Total & 40 & 58,8 & 28 & 41,2 & 68 & 100,0 & & & \\
\hline
\end{tabular}

Berdasarkan Tabel 7 dapat diketahui bahwa dari 34 orang ibu bayi yang mengatakan iklan susu formula tidak terpapar terhadap pemberian susu formula pada bayi usia 0-6 bulan, ada 21 orang ibu bayi yang tidak memberikan susu formula pada bayi usia 0-6 bulan dan 13 orang ibu bayi yang memberikan susu formula pada bayi usia 0-6 bulan sedangkan dari 34 orang ibu bayi yang mengatakan iklan susu formula terpapar terhadap pemberian susu formula pada bayi usia 0-6 bulan, ada 7 orang ibu bayi yang tidak memberikan susu formula pada bayi usia 0-6 bulan dan 27 orang ibu bayi yang memberikan susu formula.

Hasil uji Continuity Correction didapat sebesar 10,261 dengan nilai asymp.sig $\quad(\mathrm{p})=0,001$. Karena nilai $\mathrm{p}<0,05$ maka ada hubungan yang signifikan antara faktor iklan susu formula dengan pemberian susu formula pada bayi usia 0-6 bula di Wilayah Kerja Puskesmas Jembatan Kecil Kota Bengkulu. Hasil uji Contigency Coefficient (C) didapat sebesar 0,386. Karena nilai tersebut tidak terlalu jauh dari nilai $\mathrm{C}_{\max }=0,707$ maka hubungan tersebut dikatakan kategori sedang.

\section{Pembahasan}

Berdasarkan hasil penelitian dari 12 responden dengan pengetahuan kurang, terdapat $10(83,3 \%)$ responden yang memberikan susu formula dan 2 $(16,7 \%)$ responden yang tidak memberikan susu formula, hal ini karena 2 orang ibu bayi yang berpengetahuan kurang memiliki produksi ASI yang banyak sehingga mencukupi untuk bayinya. 
Hasil penelitian dari 31 responden dengan pengetahuan cukup terdapat $22(71,0 \%)$ orang ibu bayi yang memberikan susu formula pada bayinya dan $9(29,0 \%)$ orang ibu bayi yang tidak memberikan susu formula pada bayinya. Kemudian 25 responden dengan pengetahuan baik terdapat 8 $(32,0 \%)$ orang ibu bayi yang memberikan susu formula pada bayinya dan $17(68,0 \%)$ orang ibu bayi yang tidak memberikan susu formula pada bayinya. Masih adanya ibu bayi yang berpengetahuan cukup dan baik tetapi masih memberikan susu formula pada bayinya dikarenakan ASI yang dikeluarkan sedikit, pada waktu melahirkan ASI belum keluar, bekerja sehingga tidak ada waktu untuk memompa ASI, adanya pelatihan kerja dan bayi tinggal dirumah diasuh nenek sehingga untuk mencukupi kebutuhan bayinya diberikan susu formula.

Berdasarkan hasil uji Chi-Square (Pearson Chi-Square) maka ada hubungan yang signifikan antara faktor pengetahuan ibu dengan pemberian susu formula pada bayi usia 0-6 bulan di Wilayah Kerja Puskesmas Jembatan Kecil Kota Bengkulu. Hasil penelitian ini sejalan dengan penelitian yang dilakukan oleh Rombot et al (2014) yang menyimpulkan bahwa terdapat hubungan yang bermakna antara pengetahuan ibu dengan pemberian susu formula. Dibuktikan dengan hasil analisis data diperoleh nilai $p=0,0027$, $<0,05$.

Hasil dari uji Contigency Coefficient (C) maka hubungan faktor pengetahuan dengan pemberian susu formula pada bayi usia 0-6 bulan dalam kategori sedang. Artinya terdapat faktor lain yang berhubungan dengan pemberian susu formula pada bayi usia 0-6 bulan, seperti faktor kesehatan bayi, kesehatan ibu, pekerjaan ibu, faktor budaya dan faktor ekonomi.
Hasil penelitian ini sejalan dengan teori yang dikemukakan oleh Irianto (2014), pengetahuan adalah faktor yang berhubungan dengan tingkat pengenalan informasi tentang pemberian susu formula pada bayi usia kurang dari enam bulan. Pengetahuan ibu tentang kapan pemberian susu formula dan risiko pemberian susu formula pada bayi usia kurang dari enam bulan sangatlah penting. Tetapi bayak ibu-ibu yang tidak mengetahui hal tersebut diatas sehingga memberikan susu formula pada bayi usia di bawah enam bulan tanpa mengetahui risiko yang akan timbul.

Berdasakan hasil penelitian dari 18 orang ibu bayi yang mengatakan bahwa petugas kesehatan tidak menyarankan pemberian susu fomula pada bayi usia 0-6 bulan terdapat 12 $(66,7 \%)$ orang ibu tidak memberikan susu formula pada bayinya dan 6 $(33,3 \%)$ orang ibu memberikan susu formula pada bayinya, hal ini dikarenakan bayi masih merasa lapar atau tidak puas menyusu dengan ibunya sehingga ibu bayi memberikan susu formula pada bayinya, produksi ASI ibu sedikit sehingga untuk mencukupi kebutuhan bayi diberikan susu formula dan ibu sibuk bekerja sehingga diberikan susu formula.

Kemudian hasil penelitian dari 50 orang ibu yang mengatakan bahwa petugas kesehatan menyarankan pemberian susu formula pada bayi usia 0-6 bulan, terdapat $34(68,0 \%)$ orang ibu yang memberikan susu formula pada bayinya, hal ini dikarenakan ASI ibu yang sedikit, pada waktu melahirkan bayinya sudah diberikan susu fomula oleh petugas kesehatan karena ibu dan bayi berada ditempat yang terpisah, pada awal melahirkan ASI ibu belum keluar sehingga langsung diberikan susu formula dan terdapat $16(32,0 \%)$ orang ibu yang 
tidak memberikan susu formula pada bayinya dikarenakan ASI yang dikeluarkan banyak.

Hasil uji Chi-Square (Pearson ChiSquare) maka ada hubungan yang signifikan antara faktor petugas kesehatan dengan pemberian susu formula pada bayi usia 0-6 bulan di Wilayah Kerja Puskesmas Jembatan Kecil Kota Bengkulu. Hasil penelitian ini sejalan dengan penelitian yang dilakukan oleh Nurmawati et al (2015) yang menyimpulkan bahwa terdapat hubungan yang bermakna antara faktor petugas kesehatan dengan pemberian susu formula pada bayi usia 0-6 bulan. Dibuktikan dengan hasil analisis data diperoleh nilai $\mathrm{p}=0,013,<\alpha=0,05$.

Hasil dari uji Contigency Coefficient (C) maka hubungan faktor petugas kesehatan dengan pemberian susu formula pada bayi usia 0-6 bulan dalam kategori sedang. Artinya,terdapat faktor lain yang berhubungan dengan pemberian susu formula pada bayi usia 0-6 bulan seperti faktor kesehatan bayi, kesehatan ibu, pekerjaan ibu, faktor budaya dan faktor ekonomi. Hasil penelitian ini sejalan dengan teori yang dikemukakan oleh Irianto (2014) Petugas kesehatan sangat berperan dalam memotivasi ibu untuk tidak memberikan susu formula pada bayi usia kurang dari 6 bulan. Biasanya, jika dilakukan penyuluhan dan pendekatan yang baik kepada ibu yang memiliki bayi usia kurang dari 6 bulan, maka pada umumnya ibu mau patuh dan menuruti nasehat petugas kesehatan, oleh karena itu petugas kesehatan diharapkan menjadi sumber informasi tentang kapan waktu yang tepat memberikan susu formula dan resiko pemberian susu formula terlalu dini pada bayi.

Berdasarkan hasil penelitian terdapat 34 orang ibu yang terpapar dengan iklan susu formula dengan 27
$(79,4 \%)$ orang ibu yang memberikan susu formula pada bayinya, hal ini dikarenakan ibu bayi percaya iklan yang disampaikan komposisi zat gizinya yang baik bagi bayi dan anak yang diberikan susu formula sehat dan cerdas dan $7(20,6 \%)$ orang ibu yang tidak memberikan susu formula pada bayinya dikarenakan ASI banyak sehingga kebutuhan asupan makanan bayi tercukupi dan karena faktor ekonomi yang tidak memadai untuk membeli susu formula.

Kemudian hasil penelitian dari 34 orang yang tidak terpapar dengan iklan susu formula terdapat $21(61,8 \%)$ orang yang tidak memberikan susu formula pada bayinya dan $13(38,2 \%)$ orang yang memberikan susu formula pada bayinya, hal ini dikarenakan ASI yang dikeluarkan sedikit sehingga tidak mencukupi asupan makanan bayi, pada awal melahirkan ASI belum keluar, bekerja sehingga diberikan susu formula, bayi sering menangis dan dianggap masih lapar sehingga diberikan tambahan susu formula.

Hasil uji Chi-Square (Pearson Chi-Square) maka ada hubungan antara faktor iklan susu formula dengan pemberian susu formula pada bayi usia 0-6 bulan di Wilayah Kerja Puskesmas Jembatan Kecil Kota Bengkulu. Hasil penelitian ini sejalan dengan penelitian yang dilakukan oleh Siregar (2008) yang menyimpulkan bahwa terdapat hubungan yang bermakna antara faktor iklan terhadap pemberian susu formula pada bayi usia kurang dari 6 bulan. Dibuktikan dengan hasil analisis data diperoleh nilai $\mathrm{P}$ value $=0,012,<\alpha=$ 0,05 .

Hasil dari uji Contigency Coefficient (C) maka hubungan faktor iklan susu formula dengan pemberian susu formula pada bayi usia 0-6 bulan dalam kategori sedang. Artinya terdapat faktor lain yang berhubungan 
dengan pemberian susu formula pada bayi usia 0-6 bulan seperti faktor kesehatan bayi, kesehatan ibu, pekerjaan ibu, faktor budaya dan faktor ekonomi. Hasil penelitian ini sejalan dengan teori yang dikemukakan oleh Irianto (2014), yang menyatakan bahwa banyaknya iklan yang memasarkan susu formula, membuat ibu mau memberikan kepada bayi dengan kenyakinan sehat dan baik bagi bayinya. Iklan tidak hanya melalui televisi tapi juga radio dan surat kabar, bahkan di tempat-tempat praktek swasta dan klinik-klinik kesehatan masyarakat di Indonesia sudah tersedia brosur-brosur gratis tentang produkproduk susu yang bisa diberikan pada bayi usia kurang dari 6 bulan.

\section{E. Kesimpulan}

1. Dari 68 ibu, terdapat 40 ibu $(58,8 \%)$ melakukan pemberian susu formula di wilayah kerja Puskesmas Jembatan Kecil Kota Bengkulu.

2. Dari $68 \mathrm{ibu}$, terdapat $31 \mathrm{ibu}(45,6 \%)$ berpengetahuan cukup di wilayah kerja Puskesmas Jembatan Kecil Kota Bengkulu.

3. Dari 68 ibu, terdapat 50 ibu $(73,5 \%)$ mengatakan petugas kesehatan menyarankan pemberian susu formula di wilayah kerja Puskesmas Jembatan Kecil Kota Bengkulu.

4. Dari $68 \mathrm{ibu}$, terdapat $34 \mathrm{ibu}(50,0 \%)$ tidak terpapar iklan susu formula di wilayah kerja Puskesmas Jembatan Kecil Kota Bengkulu.

5. Ada hubungan yang signifikan antara pengetahuan ibu dengan pemberian susu formula pada bayi usia 0-6 bulan di wilayah kerja Puskesmas Jembatan Kecil Kota Bengkulu.

6. Ada hubungan yang signifikan antara petugas kesehatan dengan pemberian susu formula pada bayi usia 0-6 bulan di wilayah kerja Puskesmas Jembatan Kecil Kota Bengkulu.

7. Ada hubungan yang signifikan antara iklan susu formula dengan pemberian susu formula pada bayi usia 0-6 bulan di wilayah kerja Puskesmas Jembatan Kecil Kota Bengkulu.

\section{Daftar Pustaka}

Astuti, S., Judistiani, T.D., Rahmiati, L., et al. (2015). Asuhan Kebidanan Nifas dan Menyusui. Jakarta: Erlangga.

Dinkes Kota Bengkulu. (2015). Profil Kesehatan Kota Bengkulu. Bengkulu: Dinas Kesehatan Bengkulu.

Dinkes Provinsi Bengkulu. (2015). Profil Kesehatan Provinsi Bengkulu. Bengkulu. Dinas Kesehatan Bengkulu.

Gibney, M.J., Margetts, B.M., Kearney, J.M., et al. (2009). Gizi Kesehatan Masyarakat. Jakarta: EGC Medical Publisher.

Irianto,K. (2014). Gizi Seimbang dalam Kesehatan Reproduksi. Bandung: Alfabeta.

Monika, F.B., (2014). Buku Pintar ASI dan Menyusui. Jakarta: PT Mizan Publika.

Mulyani, N.S. (2013). ASI dan Pedoman Ibu Menyusui. Yogyakarta: Nuha Medika.

Nurmawati, I.,Nugraheni, S.A., \& Kartini, A. (2015). Faktor Determinan Pemberian Susu Formula pada Bayi Usia 0-6 Bulan. Jurnal Manajemen Kesehatan Indonesia Volume 03, Nomor 01. Diambil pada tanggal 13 April 2017, dari http://download.portalgaruda.or g/article.php?article $=405650 \& \mathrm{v}$ $\mathrm{al}=8839$. 
Kemenkes RI. (2013). Hasil Riset Kesehatan Dasar 2013. Jakarta : Kemenkes RI.

Rombot, G., Kandou, G.D., \& Ratag, G.A.E. (2014). Faktor-faktor yang Berhubungan dengan Pemberian Susu Formula Pada Bayi Usia -6 Bulan di Wilayah Kerja Puskesmas Molompor Tombatu Timur Minahasa Tenggara. Jurnal Kedokteran Komunitas dan Tropik, Volume 2, Nomor 2. Diambil pada tanggal 13 April 2017, dari http://download.portalgaruda.or g/article.php?aricle $=172570 \& v a$ $\underline{1=5793}$.

SDKI. (2012). Survei Demografi dan Kesehatan Indonesia. Jakarta: Badan Kependudukan dan Keluarga Berencana, Badan Pusat Statsistik, Kementerian Kesehatan.

Siregar, T.L. (2008). Faktor-Faktor yang Mempengaruhi Ibu Memberikan Makanan Tambahan pada Bayi Usia Kurang dari 6 Bulan di Wilayah Kerja Puskesmas Simpang Limun Medan. Skripsi, Fakultas Kesehatan Masyarakat, USU : Medan.

Yuliarti, N. (2010). Keajaiban ASI Makanan Terbaik untuk Kesehatan, Kecerdasan, dan Kelincahan Si Kecil. Yogyakarta : CV. Andi Offset. 